Maria STUDNICKA

Toxicology

\section{STUDIES ON MERCURY CONTENT IN MUSCLES \\ OF FISHES FROM SOME NATURAL POLISH WATER BODIES} BADANIA NAD ZAWARTOŚCIĄ RTĘCI W MIËSINIACH RYB POCHODZACYCH
Z NIEKTÓRYCH NATURALNYCH ZBIORNIKÓW WODNYCH POLSKI

\author{
Institute of Inland Fisheries, Olsztyn
}

Total mercury contents were determined in muscles of 16 fish species caught in the river Vistula, its tributaries, and the Eęczyca-Włodawa lakes. All the Vistula fishes examined showed much higher mercury contents compared to those found in fishes from unpolluted waters; mercury contents in many predatory fishes exceed $0.5 \mathrm{mg} / \mathrm{kg}^{-1}$.

\title{
INTRODUCTION
}

A wide application of mercury and its compounds and a constantly increasing use there of combined with a lack or a poor efficiency of sewage and smoke treatment installations cause a steady increase in pollution of the natural environment and pose a danger of toxic effects. Particularly vulnerable to this element or its compounds are water habitats. Most of the mercury content enters the waters via industrial wastes and precipitation (Anderson et al., 1973).

Mercury entering a water habitat is accumulated in organisms living in it. Both methyl-mercury and inorganic mercury compounds show an affinity to sulpho groups of proteins (Gavis and Ferguson, 1972) and for this reason are rather permanently bound in an organism. Owing to a low excretion rate they tend to accumulate in the organism affected. 
The mercury accumulation in fish tissues depends on a compound in question and its content in the environment, water temperature, and fish species (Barber et al., 1972; Gilespie and Scott, 1971; Hannerz, 1968; Hasselrot, 1968; Kramer and Neidhart, 1975; Tsai et al., 1975).

Various sympatric fish species can show markedly differing mercury contents, which is related to differences in metabolic processes of each species. Predatory fishes, pike in particular, tend to accumulate higher quantities of mercury; the species is therefore regarded as an indicator for determining thedegree of mercury contamination in the aquatic habitat (Fageström et al., 1974; Fageström et al., 1975; Johnels et al., 1967; Johnels et al., 1968).

The present studies were aimed at determining the total mercury level in muscles of various fish species in the river Vistula.

Assuming the river to be polluted with industrial wastes, possibly the same species from unpolluted rivers and lakes were examined, too. The present work is a continuation of the author's studies on heavy metal contamination in fishes in Poland and Czechoslovakia (Hejtmanek et al., 1975; Studnicka, 1974; Studnicka et al., 1974; Svobodová et al., 1975 a; Svobodová et al., 1975 b).

\section{MATERIAL AND METHODS}

Total mercury was determined in muscles of 582 fish individuals belonging to 16 species.

Specimens from unpolluted waters were obtained from upper reaches of the following Vistula tributaries: Skawa, Dłubnia, and San, as well as from the river Tanew and the following Łęczyca-Włodawa lakes: Dratów, Łukcze, Rotcze, Sumin, Miejskie, and Kunów. The water bodies listed above yielded 94 individuals belonging to 10 species.

In the Vistula, known to carry a large load of industrial pollution, the fishes were caught at four sites: near Cracow, Puławy, Swiecie, and Swibno (at the river mouth). Decisive for the selection of capture sites was the location of fishermen's cooperatives regularly fishing the species studied on the commercial basis.

Owing to a considerable pollution of the Vistula near Cracow with various toxic substances, only a small number of fish species is found to live there. Those fishes are not fit for consumption, no regular fishing is therefore carried out there; the material to be examined, consisting of 40 individuals belonging to 3 species had to be caught with a fishing rod.

The samples obtained near Puławy and Swiecie consisted of 166 individuals belonging to 10 species and 125 individuals representing 8 species, respectively. Near Swibno, the mercury content was determined in muscles of 147 individuals belonging to 8 species.

The distribution of species among the capture sites is presented in Table 1 .

The individuals caught were kept in polythene bags at $-20^{\circ} \mathrm{C}$. Each $5 \mathrm{~g}$ sample was taken from the central part of the supra-axial muscle. The sample was subject to wet 
Species studied at various capture sites

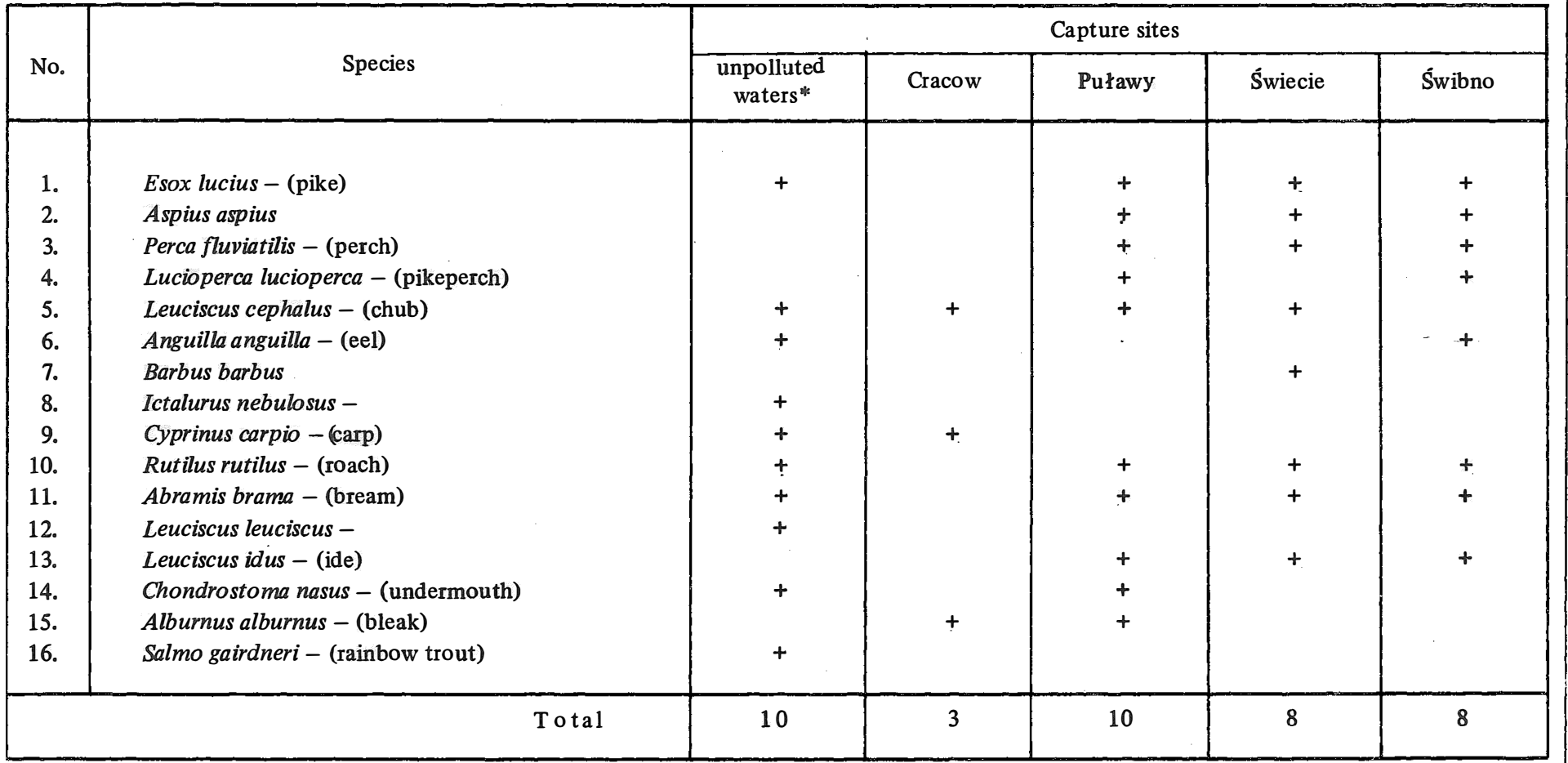

* upper reaches of Skawa, Dłubnia, San; river Tanew; Łęczyca-Włodawa lakes 
Total mercury content in muscles of fishes from unpolluted lakes and rivers

\begin{tabular}{|c|c|c|c|c|c|}
\hline \multirow{2}{*}{ Species } & \multirow{2}{*}{ Capture site } & \multirow{2}{*}{$\begin{array}{c}\text { Fish weight } \\
\text { (g) }\end{array}$} & \multirow{2}{*}{$\begin{array}{r}\text { No of } \\
\text { samples }\end{array}$} & \multicolumn{2}{|c|}{$\mathrm{Hg}$ content ( $\left.\mathrm{mg} \mathrm{kg}^{-1}\right)$} \\
\hline & & & & Range & Mean \\
\hline $\begin{array}{l}\begin{array}{c}\text { Esox lucius } \\
\text { (pike) }\end{array} \\
\quad, \\
\quad, \\
\text { Ictalurus nebulosus } \\
\text { Ansuilla anguilla (eel) } \\
\text { Rutilus rutilus (roach) } \\
\text { Abramis brama (bream) } \\
\text { Cyprinus carpio (carp) } \\
\text { Leuciscus cephalus (chub) } \\
\text { Leuciscus cephalus (chub) } \\
\text { Leuciscus cephalus (chub). } \\
\text { Chondrostoma nasus } \\
\text { (undermouth) } \\
\text { Leuciscus leuciscus } \\
\text { Salmo gairdneri } \\
\text { (rainbow trout) }\end{array}$ & $\begin{array}{l}\text { Lake Sumin } \\
\text { Lake Dratów } \\
\text { Lake Firlej } \\
\text { Lake Kunów } \\
\text { Lake Miejskie } \\
\text { Lake Rotcze } \\
\text { Lake Eukcze } \\
\text { Lake Eukcze } \\
\text { Lake Lukcze } \\
\text { river Tanew } \\
\text { river Skawa } \\
\text { river San } \\
\text { river Tanew } \\
\text { river Tanew } \\
\text { river Dłubnia }\end{array}$ & $\begin{array}{l}350-950 \\
350-960 \\
800-1650 \\
840-1700 \\
60-96 \\
700-1500 \\
50-70 \\
300 \\
50-150 \\
80-96 \\
130-170 \\
80-100 \\
390 \\
45-100 \\
150\end{array}$ & $\begin{array}{r}16 \\
5 \\
5 \\
4 \\
10 \\
4 \\
5 \\
1 \\
15 \\
4 \\
15 \\
3\end{array}$ & $\begin{array}{c}0.095-0.120 \\
0.085-0.125 \\
0.070-0.150 \\
0.060-0.160 \\
0.037-0.111 \\
0.040-0.085 \\
0.033-0.057 \\
0.033 \\
0.006-0.042 \\
0.030-0.060 \\
0.020-0.047 \\
0.006-0.016 \\
0.086 \\
0.030-0.095 \\
0.007\end{array}$ & $\begin{array}{c}0.106 \pm 0.01 \\
0.103 \pm 0.01 \\
0.100 \pm 0.02 \\
0.090 \pm 0.04 \\
0.064 \pm 0.02 \\
0.058 \pm 0.02 \\
0.046 \pm 0.02 \\
0.033 \\
0.025 \pm 0.02 \\
0.050 \pm 0.01 \\
0.029 \pm 0.04 \\
0.011 \pm 0.01 \\
0.086 \\
0.065 \pm 0.02 \\
0.007\end{array}$ \\
\hline
\end{tabular}




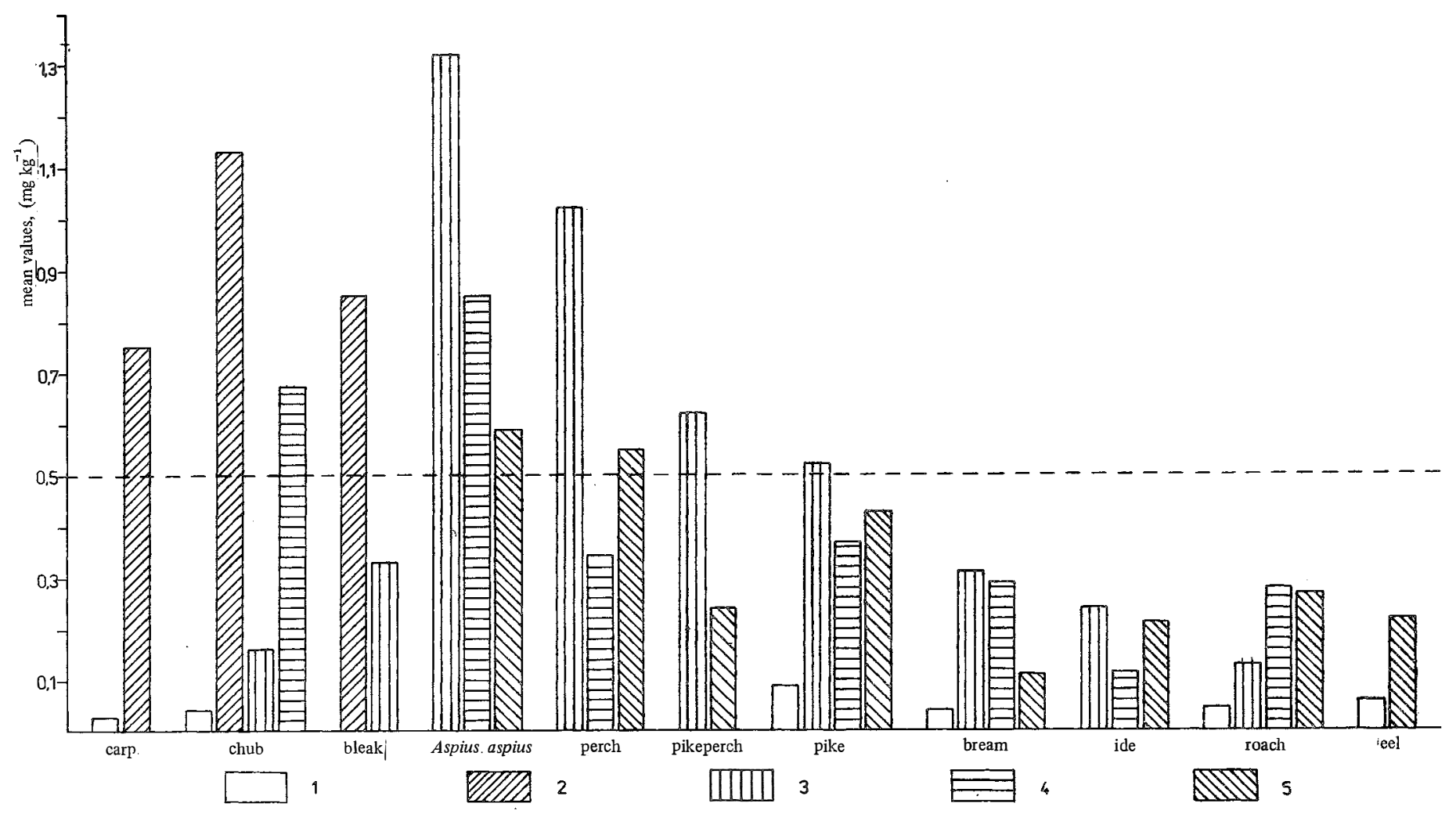

Fig. 1. Total mercury content in muscles of fishes from various capture sites 1. unpolluted waters; 2. Cracow; 3. Puławy; 4. Świecie; 5. Swibno 
mineralization with nitric and sulphuric acids in a closed system (Szprengier, 1972; Żmudzki and Szprengier, 1973). Total mercury was determined by atomic absorption spectrophotometry in a Coleman MAS-50 (Perkin-Elmer) analyzer at the Department of Pharmacology and Toxicology, Institute of Veterinary Medicine (Puławy) and in an EEL 240 (Evans) atomic absorption spectrophotometer at the Central Laboratory, Academy of Agriculture (Lublin). Of the latter batch, some samples of a particularly high mercury content were checked at the Chair of Analytical Methods, Chemical-Technological College (Praha, Czechoslovakia).

The results obtained were subject to a statistical treatment.

\section{RESULTS}

Tables 2-6 summarize the total mercury contents in the fishes studied at various capture sites.

When analyzing the results obtained, the following data should be given a particular attention:

1. The total mercury content in those fishes caught from unpolluted lakes and rivers (Table 2) ranged within $0.006-0.16 \mathrm{mg} \mathrm{kg}^{-1}$.

2. Of all the species obtained from clean water bodies, the highest mercury content, $0.06-0.16 \mathrm{mg} \mathrm{kg}^{-1}$ (a mean of $0.1 \mathrm{mg} \mathrm{kg}^{-1}$ ) was found in pike.

3. About $95 \%$ of all the individuals from those water bodies showed mercury contents below $0.1 \mathrm{mg} \mathrm{kg}^{-1}$.

4. Individuals belonging to the same species but caught at different, sometimes very far apart, unpolluted lakes or rivers showed similar muscle mercury contents, which is clearly seen when comparing the mercury contents in chub or pike (Table 2).

5. All the Vistula fishes yielded much higher mercury contents compared to their counterparts from unpolluted waters (Table 7; Fig. 1).

Total mercury content in muscles of fishes caught from the Vistula near Cracow

\begin{tabular}{|c|c|c|c|c|}
\hline Species & $\begin{array}{c}\text { Fish weight } \\
(\mathrm{g})\end{array}$ & No. of & \multicolumn{2}{|c|}{ samples content $\left(\mathrm{mg} \mathrm{kg}^{-1}\right)$} \\
\cline { 4 - 5 } & $90-120$ & 15 & Range & Mean s \\
\hline $\begin{array}{c}\text { Leuciscus cephalus } \\
\text { (chub) }\end{array}$ & $18-25$ & 20 & $0.93-1.30$ & $1.150 \pm 0.06$ \\
$\begin{array}{c}\text { Alburnus alburnus } \\
\text { (bleak) }\end{array}$ & $80-110$ & 5 & $0.69-0.95$ & $0.050 \pm 0.25$ \\
$\begin{array}{c}\text { Cyprinus carpio } \\
\text { (carp) }\end{array}$ & & & 0.04 \\
\hline
\end{tabular}

$s= \pm$ standard deviation 
Total mercury content in muscles of fishes caught from the Vistula near Pulawy

\begin{tabular}{|c|c|c|c|c|}
\hline \multirow{2}{*}{ Species } & \multirow{2}{*}{$\begin{array}{c}\text { Fish } \\
\text { weight }(\mathrm{g})\end{array}$} & \multirow{2}{*}{$\begin{array}{c}\text { No. of } \\
\text { samples }\end{array}$} & \multicolumn{2}{|c|}{$\mathrm{Hg}$ content ( $\left.\mathrm{mg} \mathrm{kg}^{-1}\right)$} \\
\hline & & & Range & Mean \\
\hline Aspius aspius & $1000-1350$ & 2 & $1.350-1.362$ & 1.356 \\
\hline Perca fluviatilis (perch) & $80-300$ & 12 & $0.586-1.581$ & $1.083 \pm 0.49$ \\
\hline Lucioperca lucioperca & & & & \\
\hline (pikeperch) & $600-800$ & 16 & $0.606-0.648$ & $0.626 \pm 0.04$ \\
\hline Esox lucius (pike) & $300-850$ & 16 & $0.509-0.595$ & $0.565 \pm 0.03$ \\
\hline $\begin{array}{l}\text { Alburnus alburnus } \\
\text { (bleak) }\end{array}$ & $20-30$ & 12 & $0.300-0.390$ & $0.325 \pm 0.03$ \\
\hline Abramis 3rama & & & & \\
\hline (bream) & $140-340$ & 26 & $0.217-0.437$ & $0.312 \pm 0.09$ \\
\hline Leciscus idus (ide) & $280-646$ & 29 & $0.100-0.495$ & $0.240 \pm 0.15$ \\
\hline $\begin{array}{l}\text { Chondrostoma nasus } \\
\text { (undermouth) }\end{array}$ & $330-800$ & 11 & $0.219-0.329$ & $0.224 \pm 0.03$ \\
\hline $\begin{array}{l}\text { Leuciscus cephalus } \\
\text { (chub) }\end{array}$ & $40-125$ & 18 & $0.117-0.166$ & $0.152 \pm 0.01$ \\
\hline $\begin{array}{l}\text { Rutilus rutilus } \\
\text { (roach) }\end{array}$ & $30-110$ & 24 & $0.072-0.239$ & $0.129 \pm 0.04$ \\
\hline
\end{tabular}

$s= \pm$ standard deviation

Total mercury content in muscles of fishes caught from the Vistula near Swiecie

\begin{tabular}{|l|c|c|c|c|}
\hline \multirow{2}{*}{ Species } & \multirow{2}{*}{$\begin{array}{c}\text { Fish } \\
\text { weight (g) }\end{array}$} & $\begin{array}{c}\text { No. of } \\
\text { samples }\end{array}$ & \multicolumn{2}{|c|}{ Hg content $\left(\mathrm{mg} \mathrm{kg}^{-1}\right)$} \\
\cline { 4 - 5 } & $550-2360$ & 14 & $0.350-1.119$ & $0.862 \pm 0.32$ \\
\hline $\begin{array}{l}\text { Aspius a spius - } \\
\text { Leuciscus cephalus } \\
\text { (chub) }\end{array}$ & $700-1600$ & 12 & $0.480-0.880$ & $0.680 \pm 0.20$ \\
Barbus barbus - & 920 & 1 & 0.500 & 0.500 \\
Esox lucius - (pike) & $230-420$ & 19 & $0.290-0.470$ & $0.364 \pm 0.07$ \\
Perca fluviatilis & $50-170$ & 25 & $0.205-0.379$ & $0.362 \pm 0.03$ \\
$\quad$ (perch) & $180-620$ & 19 & $0.120-0.430$ & $0.294 \pm 0.80$ \\
Abramis brama (bream) & $130-430$ & 17 & $0.220-0.540$ & $0.272 \pm 0.35$ \\
Rutilus rutilus (roach) & $110-250$ & 18 & $0.103-0.280$ & $0.115 \pm 0.11$ \\
Leuciscus idus (ide) & & & & \\
\hline
\end{tabular}

$s= \pm$ standard deviation 
Total mercury content in muscles of fishes caught from the Vistula near Swibno

\begin{tabular}{|c|c|c|c|c|}
\hline \multirow{2}{*}{ Species } & \multirow{2}{*}{$\begin{array}{c}\text { Fish } \\
\text { weight }(\mathrm{g})\end{array}$} & \multirow{2}{*}{$\begin{array}{l}\text { No. of } \\
\text { samples }\end{array}$} & \multicolumn{2}{|c|}{$\mathrm{Hg}$ content (mg kg${ }^{-1}$ ) } \\
\hline & & & Range & Mean \\
\hline Aspius aspius - & $800-2100$ & 17 & $0.371-0.880$ & $0.594 \pm 0.18$ \\
\hline Perca fluviatilis (perch) & $100-420$ & 22 & $0.249-0.894$ & $0.551 \pm 0.26$ \\
\hline $\begin{array}{l}\text { Esox lucius } \\
\quad \text { (pike) }\end{array}$ & 350 & 1 & 0.432 & 0.432 \\
\hline $\begin{array}{l}\text { Rutilus rutilus } \\
\text { (roach) }\end{array}$ & $180-830$ & 23 & $0.100-0.400$ & $0.265 \pm 0.09$ \\
\hline $\begin{array}{l}\text { Lucioperca lucioperca } \\
\text { (pikeperch) }\end{array}$ & $750-2500$ & 20 & $0.174-0.455$ & $0.237 \pm 0.08$ \\
\hline $\begin{array}{l}\text { Anguilla anguilla } \\
\quad \text { (eel) }\end{array}$ & $200-1650$ & 38 & $0.021-0.460$ & $0.226 \pm 0.08$ \\
\hline Leuciscus idus (ide) & $250-490$ & 17 & $0.143-0.280$ & $0.212 \pm 0.04$ \\
\hline $\begin{array}{l}\text { Abramis brama } \\
\text { (bream) }\end{array}$ & $50-400$ & 19 & $0.043-0.125$ & $0.111 \pm 0.02$ \\
\hline
\end{tabular}

$s= \pm$ standard deviation

6. All the Vistula fishes caught in the vicinity of Cracow showed their muscle mercury contents to exceed $0.5 \mathrm{mg} \mathrm{kg}^{-1}$ (Table 3).

7. Muscles of predatory species (Aspius aspius, perch, pikeperch, pike) contained more mercury than those of omnivorous (chub, eel) or herbivorous species caught at the same sites (Table 7; Fig. 1).

8. Among the species caught at various Vistula sites, the Aspius aspius individuals showed the highest mean mercury content (Tables 4,5 , and 6 ).

\section{DISCUSSION}

The total mercury contents found in muscles of the examined fishes from unpolluted waters are within the range $\left(0.006-0.16 \mathrm{mg} \mathrm{kg}^{-1}\right)$ accepted as a "natural level". Values similar to those reported here were found by other authors working on fishes from various unpolluted water bodies (Aronson et al., 1976; Studnicka et al., 1974; Svobodová et al., 1975; Weigand-Eschraghi et al., 1971; Zitko et al., 1971). As shown by the existing literature, muscle mercury levels in fishes of various species inhabiting unpolluted waters do not differ in any significant way. On the other hand, in polluted waters much higher mercury contents are found in predatory species than in omni- and herbivores 
(Hajtmànek et al., 1975; Svobodová et al., 1975; Uthe and Bligh, 1971; Wobeser et al., 1970). The data obtained in the present study corroborate previous results.

The results obtained in the present study show all the Vistula species tested, regardies of the capture site, to be of a higher mercury content (up to $1.581 \mathrm{mg} \mathrm{kg}^{-1}$ ) than the fishes caught in the unpolluted water bodies. The degree of pollution tends to vary along the Vistula course, which can be seen by comparing mercury contents in muscles of conspecific individuals of a similar weight caught ar various sites (Table 7; Fig. 1 ).

All the fishes caught in the vicinity of Cracow (Table 3; Fig. 1) showed their mercury contents in muscles to exceed $0.5 \mathrm{mg} \mathrm{kg}^{-1}$, i.e., a content proposed by $\mathbb{F A O} / \mathrm{WHO}$ as the highest content permitted in marketed fish (Technical Reports, 1972). Among the species caught off Cracow, chub was found to have the highest mercury content (a mean of $1.15 \mathrm{mg} \mathrm{kg}^{-1}$ ) whereas chub caught in the unpolluted rivers (upper reaches of San, Skawa, and Tanew) showed much lower mercury contents (a mean of $0.03 \mathrm{mg} \mathrm{kg}^{-1}$ ). A considerable contamination of all the fishes caught off Cracow proves a high degree of pollution to occur in that part of the Vistula brought about - as should be assumed - by a substantial amount of wastes released by numerous industrial plants. This pollution inctodes, apart from mercury, other substances toxic for fishes, which is evidenced by a scanty ichthyofauna in that part of the river.

Table 7

Mean total mercury content ( $\mathrm{mg} \mathrm{kg^{-1 }}$ ) in muscles of fishes from various capture sites

\begin{tabular}{|c|c|c|c|c|c|c|}
\hline \multirow[b]{2}{*}{ No. } & \multirow[b]{2}{*}{ Species } & \multicolumn{5}{|c|}{ Capture site } \\
\hline & & $\begin{array}{l}\text { Unpolluted } \\
\text { waters* }\end{array}$ & Cracow & Pukawy & Świecie & Świbno \\
\hline 1 & Esox lucius & 0.100 & & 0.565 & 0.364 & 0.432 \\
\hline 2 & Aspius aspius & & & 1.356 & 0.862 & 0.594 \\
\hline 3 & Perca fluviatilis & & & 1.083 & 0.362 & 0.551 \\
\hline 4 & Lucioperca lucioperca & & & 0.626 & & 0.237 \\
\hline 5 & Leuciscus cephalus & 0.030 & 1.150 & 0.152 & 0.680 & \\
\hline 6 & Anguilla anguilla & 0.058 & & & & 0.226 \\
\hline 7 & Barbus barbus & & & & 0.500 & \\
\hline 8 & Ictalurus nebulosus & 0.064 & & & & \\
\hline 9 & Cyprinus carpio & 0.025 & 0.797 & & & \\
\hline 10 & Rutilus rutilus & 0.046 & & 0.129 & 0.272 & 0.265 \\
\hline 11 & Abramis brama & 0.033 & & 0.312 & 0.294 & 0.111 \\
\hline 12 & Leuciscus leuciscus & 0.065 & & & & \\
\hline 13 & Leuciscus idus & & & 0.240 & 0.115 & 0.212 \\
\hline 14 & Chondrostoma nasus & 0.086 & & 0.224 & & \\
\hline 15 & Alburnus alburnus & & 0.850 & 0.325 & & \\
\hline 16 & Salmo gairdneri & 0.007 & & & & \\
\hline
\end{tabular}

* upper reaches of Skawa, Dłubnia, San; river Tanew; Eęczyca-Włodawa Lakes 
In the vicinity of Puławy, mercury contents exceeding $0.5 \mathrm{mg} \mathrm{kg}^{-1}$ were found only in the predatory species ( $A$. aspius, perch pikeperch, pike) (Table 4; Fig. 1 ). This part of the Vistula yields fish for consumption. According to a standard proposed for Poland $\left(0.5 \mathrm{mg} \mathrm{kg}^{-1}\right.$; Szprengier, 1976) it follows that the predatory species caught in that part of the river should not be allowed for consumption. The decision banning the marketing of those fishes should be, however, preceded by periodical checks of the fish mercury content.

When analyzing the mercury contamination in the fishes caught in the vicinity of Swiecie, a lower mercury content is observed compared to the fishes caught off Puławy (Fig. 1). It was only in two species (A. aspius and chub) that a mean mercury content exceeded $0.5 \mathrm{mg} \mathrm{kg}^{-1}$. With respect to the predatory species, no pike or perch individual showed a mercury content exceeding $0.5 \mathrm{mg} \mathrm{kg}^{-1}$.

The degree of mercury contamination in herbivores and benthosfeeders caught off Swiecie (Table 5; Fig. 1) was also lower than off Puławy in spite of the fact that those fishes were usually heavier (bream and roach in particular) and as such they should have been expected to have accumulated more mercury in their muscles. It seems probable that this was the reason of a high mercury content in chub caught in this part of the river. Those fishes weighet up to $1600 \mathrm{~g}$, their mean mercury content being $0.68 \mathrm{mg} \mathrm{kg}^{-1}$, while much smaller (40-125 g) individuals of the species caught off Puławy showed a mean mercury content of $0.15 \mathrm{mg} \mathrm{kg}^{-1}$. Older chub, however, switch to a predatory mode of feeding. This factor seems thus to play a key role in increasing the mercury content in those individuals caught in the vicinity of Swiecie.

The results obtained can serve as a basis for a general conclusion that the Vistula in the vicinity of Swiecie is mercury-polluted to a lesser extent than off Puławy.

The results obtained in the vicinity of Swibno (Table 6; Fig. 1) allow no specific conclusion on the pollution extent in that part of the river to be drawn.

A lower mercury content there as compared to the vicinity of Swiecie was found in A. aspius and bream. The latter was, however, represented by individuals of a lower weight than off Swiecie. Muscles of another two species, perch and ide, showed a higher mercury content off Swibno than in the vicinity of Swiecie, which cauld have resulted from a larger size, and consequently an older age of the Siwibno individuals.

Although $A$. aspius and perch in that part of the Vistula showed a mean mercury content exceeding $0.5 \mathrm{mg} \mathrm{kg}^{-1}$, which - according to a proposed Polish standard - is more than the permitted level, it should be stressed that $50 \%$ of the individuals of the two species showed their mercury contents to be below that value, as was the case in all pikeperch and pike individuals caught in that part of the river.

Among all the species examined, the Swibno bream muscles showed the lowest mercury content ranging within $0.043-0.0125 \mathrm{mg} \mathrm{kg}^{-1}$, i.e., close to the "natural level" found in bream from the unpolluted waters (Table 7). The mercury content was close to the "natural level" also in $25 \%$ of eel individuals tested.

Similar mercury contents were found by Nabrzyski (1975) in fishes from the lower reach of the Vistula and Nogat. 
Generally speaking, the degree of mercury contamination in the Vistula fishes is found to be considerable, particularly in the predatory species. Herbivores and benthos-feeders showed their muscle mercury contents to be below $0.5 \mathrm{mg} \mathrm{kg}^{-1}$ (except for those individuals caught in the vicinity of Cracow). The data suggest a straightforward relationship to exist between the degree of mercury accumulation and food chain length.

The Vistula fish mercury contamination is similar to that found in fishes from various European countries. Muscles of fishes caught at various sites along the entire course of the Vltava (Czechoslovakia), showed the total mercury contents below $0.5 \mathrm{mg} \mathrm{kg}^{-1}$ (Studnicka et al., 1974), while $26 \%$ of those analyzed from the river Ohře and its tributary Reslava crossing an industrialized region of the country showed their mercury contents to exceed this level (Svobodová et al., 1975 a). Fishes from the West Germany section of the Danube revealed a mean mercury content ranging from 0.20 to $0.87 \mathrm{mg} \mathrm{kg}^{-1}$, depending on the species (Knöppler and Dorn, 1976). The fish muscle mercury contents in various water bodies of the Federal Republic of Germany showed a mean value of $1.9 \mathrm{mg} \mathrm{kg}^{-1}$ (Dietz and Koppe, 1972). In other studies, the fishes from the Danube in the southern part of the FRG showed a high mercury content (0.4-1.9 $\mathrm{mg} \mathrm{kg}^{-1}$; Wiesner, 1972). The fishes from running waters of that country showed their mercury contents lower than those found in dam reservoir fishes by the factor of 8 (Wiesner, 1972). The Danube and its tributaries in Austria is relatively weakly polluted: in $60 \%$ of the fishes examined, the muscle mercury content was below $0.5 \mathrm{mg} \mathrm{kg}^{-1}$, the highest value amounting to $1.9 \mathrm{mg} \mathrm{kg}^{-1}$ (Krocza et al., 1975). A high mercury content was recorded in the fishes caught in the Danube off Vienna (Otte et al., 1973). Fishes from lakes and rivers of central Italy are substantially mercury-contaminated, particularly those from the river Pescara receiving wastes of large industrial plants. The fishes from that river showed the mercury content ranging within $0.48-19.30 \mathrm{mg} \mathrm{kg}^{-1}$. The mercury content in fish muscles in other Italian rivers did not exceed $0.63 \mathrm{mg} \mathrm{kg}^{-1}$ (Caracciolo et al., 1972). Eel caught in various Dutch water bodies showed a much higher mercury contamination (Nuijt and Velden, 1973) than eel from Świbno. A high mercury content was found also in fishes from Scandinavian waters, considerably polluted with industrial wastes (Berlund and Wretling, 1967; Berlund et al., 1970; Westöö and Rydälv, 1971).

\section{CONCLUSIONS}

1. The river Vistula fishes, particularly those caught in the vicinity of Cracow, are highly contaminated with mercury compounds. The total mercury content in all the Cracow fishes examined and in many species (particularly predators) from other parts of the river was found to exceed $0.5 \mathrm{mg} \mathrm{kg}^{-1}$, i.e., the value determined by FAO/WHO and proposed for Poland as the highest permitted level in fish for consumption. It follows that the marketed Vistula fises (particularly the predatory species) should be periodically checked for the degree of their mercury contamination. 
2. Mercury accumulation was found to be higher in the predatory species and in larger individuals than in herbivores and smaller ones, which seems to result from a gradually increasing mercury compound concentration in tissues occurring both in consecutive links of food chains (in the predators) and during extended time periods (in older individuals).

\section{REFERENCES}

Anderson A.A., Anderson J.M., Mayer L.E., 1973: System simulation to identify environmental research needs, mercury contamination. - Oikos, 24, $2: 231-238$.

Aronson J.L., Spiesman M., Aronson A.K., 1976: Note on the distribution of mercury in fish species in three Ohio Lakes. - Environ. Pollut., 10, $1: 1-7$.

Barber $\mathbb{R}_{\text {. }}$ o, Vijavakumar A., Cross $\mathbb{F}_{\text {.A.A. }}$ 1972: Miercury concentrations in recent and minety-year-old benthopelagic fish. - Science, 178, 4061:636-639.

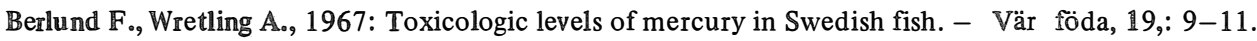

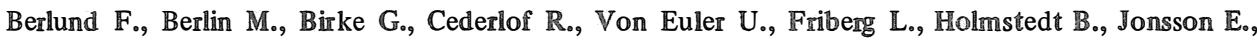
Luning $\mathbb{K}_{\circ}$, 1970: Methylmercury in fish. A toxicologisk-epidemiologisk evaluation of risks. Nord. Hyg. Tidskr., Suppl., 3: 1-313.

Caracciolo S., Di Silvestro C., Loreti A., Perna A., Travaglin N., 1972: Risultati di una indagine sul contenuto in mercurion totale di alcuni allevamenti agricoli ed industriali e di alcuni fiumi e laghi dell'italia centrale. - Nuova vet. 48, $5: 272-279$.

Diet $\mathbb{F}_{\text {o, Koppe }} \mathbb{P}_{\text {o, }}$ 1972: Untersuchungen über den Gehalt an Schwernmetallen in Süsswasserfischen. - Veröff. Inst. Künstenund Binnenfisch, 53,: 44-55.

Fageström T., Asell B., Jernelöv A., 1974: Model for accumulation of me thyl mercury in northen pike Esox lucius. - Oikos, 25, $1: 14-20$.

Fageström T., Kurten $\mathbb{R}_{\text {。g }}$ Asell B., 1975: Statistical parameters as criteria in model evaluation kinetics of mercury acumulation in pike Esox lucius. - Oikos, 26, $2: 109-116$,

Gavis J., Ferguson $\mathbb{J}_{.} \mathbb{F}_{\circ}, 1972$ : The cycling of mercury trough the environment. - Wat. Res., 6 : 989-1008.

Gilespie D.C., Scott D.P., 1971: Mobilization of mercuric sulfide from sediment into fish under aerobic conditions. - J. Fish. Res. Board. Can., 28, 11 : 1807-1808.

Hannerz L., 1968: Experimental investigations on the accumulation of mercury in water organism. Rep. Inst. Freshwat. Res. Drottningholm, 48, $1: 120-176$.

Hasselrot T.B., 1968: Report on current field investigations concerning the mercury content in fish, bottom sediment, and water. - Rep. Inst. Freshwat. Res. Drottningholrn, 48, 1 : 102-111.

Hejtmànek M., Svobodová Z., Studnicka M., 1975: Total mercury content in the musculature of fishes from some dam lakes in Bohemia. - Acta Vet. Brno, 44 : 53-58.

Johnels A.G., Westermark T., Berg W., Persson P.I., Strand B., 1967: Pike (Esox lucius L.) and some other aquatic organisms in Sweden as indicators mercury contamination of the environment. Oikos, 18, 2 : 323-333.

Johnels A.G., Olsson M., Westermark T., 1968: Esox lucius and some other organisms as indicators of mercury contamination in Swedish Lakes and Rivers. - Bull. Off. int. Epiz., 69, 9/10: $1439-1452$.

Knöppler $\mathbb{H}$. O., Dorn $\mathbb{P}_{\circ}$, 1976: Untersuchungen von Süsswasserfischen auf Quecksilber- und Pestizidrü ckstände. - Arch. Lebensmittelhyg., 27, $1: 23-26$.

Kramer H.J., Neidhart B., 1975: The behaviour of mercury in the system water. Fish. Bull. Environ. Cont. Toxicol., 14, $6: 669-704$. 
Krocza W., Haidl W., Weidenholzer Wog Stöckll W., 197j: Über die Quecksilberkontamination von Fischen aus den Salzkammergutseen Oberösterreich und der oberösterreichischen Donau. Wien. tierärztl. Monatsschr., 62, $11: 405-410$.

Mercury contamination in man and his environment. Technical Reports Series No 137, International Atomic Energy Agency, Vienna 1972.

Nabrzyski Ma, 1975: Zawartość rięci, miedzi i cynku w tkance mięsnej niektórych ryb słodkowodnych. [Mercury, copper and zinc contents in flesh of some freshwater fishes]. - Bromat. Chem. Toksykol., 8, 3: 311-319.

Nuijt $\mathbb{M}_{\circ} \mathbb{F}_{\circ}$, Velden $\mathbb{H}_{\circ}, 1973$ : The influence of weight place of and capture on the mercury content of some dutch eels. - Lebensm. - Untersuch. Forsch., 151 , 2: 89-94.

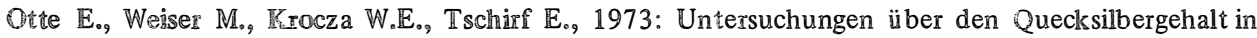
Fischen heimischer Gewasser. - Üster. Fisch., 26, 4:53-56.

Studnicka Mo, 1974: Zawartość ręci w tkankach iroci (Salmo trutta morpha trutta L.) odłowionych przy ujściu Wisty. [Mercury content in tissues of trout (Salmo trutta morpha trutta L.) caught at the river Vistula mouth]. - Medycyna Wet., 30, 12: 739-741.

Strudnicka M., Hejtimanek M., Svobodová Z ., 1974: Determination of mercury contents in muscles of fishes from the river Vitava and its tributary streams. - Acta Vet. Brno, 43, $1: 145-151$.

Svobodiová Z $\mathbb{Z}$, Hiajtmarek M., Studnicka M., 1975: Sledovani obsahu celkovértuti v rybách Českych vod. Závérečna zprava VURH Vodriany: 1-62. [in Czech].

Swobudoví $\mathbb{Z}_{\text {. }}$ Stadnicka Mo, Hejumanek Mo, 1975: Obsah célkové rtuti ve svalovinéryb a v sedimentach rybniku napájených Yekou Blanici na Vodñansku. Buletin VURH Vodřany, 1 : 18-20 [in Czech].

Szprengier $\mathbb{T}_{0}, 1972$ : Oznaczanie rtęci w materiale biologicznym. 【Mercury determination in biological materials]. - Medycyna Wet., 28, 2:116-119.

Szprengier $\mathbb{T}_{0}, 1976$ : Badania nad zawartościa rtęci w thankach zwierząt domowych w Polsce rozprawa doktorska. [Studies on mercury content in tissues of domestic animals in Poland Ph. D. Thesis].

Tsai $\mathbb{S}_{\circ} \mathbb{C}_{\circ}$ Mallory $\mathbb{G}_{\text {og }}$ Matsumura $\mathbb{F}$. , 1975: Importance of water $\mathrm{pH}$ in accumulation of organic mercury in fish. - Bull. Environ. Cont. Toxicol., 13, 2:188-193.

Uthe $\mathbb{J} . \mathbb{F}_{\circ}, \mathbb{B}$ ligh $\mathbb{E}_{\circ} \mathbb{G}_{\circ}, 1971$ : Preliminary survey of heavy metal contamination of canadian freshwater fish. - J. Fish. Res. Board Can., 28, 5: 786-788.

Weigand-Eschraghi B., Stelte Wo, Feldheim W., 1971: Wiss. Veröff. aus dem Gebiet ,Spurenelemente und Emährung”, Heft 1 , Quecksilber, Justus Liebig Universität Giessen, 139.

Westöö G. Rydälv Mog 1971: Metylkvicksilverhater fisk fánged mars 1968-april 1971. - Vår föda, 23, $7 / 8: 179-321$.

Wiesner $\mathbb{E}_{\text {. }}$ 1972: Hohe Quecksilberwerte bei Fischen der Donau und Lechstane in Nordschwaben. Veröff. Inst. Küsten Binnenfish, $53:$ 90-99.

Wobeser $\mathbb{G}_{\text {o, }}$ Nielsen $N . O$., Dunlop $\mathbb{R}_{\text {. }} \mathbb{H}_{\text {。g }}$ Atton $\mathbb{F} . \mathbb{M}_{\text {og }}$ 1970: Mercury concentrations in tissues of fish from the Saskatchewan River. - J. Fish. Res. Board Can., 27, 4: 830-834.

Zitko V., Finlayson B.J., Wildish D.J., Anderson J.M., Kohler A.C., 1971: Methylmercury in freshwater and marine fishes in Nev Brunswick in the bay of Fundy and on the Nova Scotia banks. - J. Fish. Res. Board Can., 28, 9: 1285-1291.

Z̊mudzki J., Szprengier To, 1973: Oznaczanie rtęci w materiale biologicznym metodą bezpłomieniowej spektrofotometrii atomowo-absorbcyjnej. [Mercury determination in biologic material by means of flameless atomic absorption spectrophotometry]. - Medycyna Wet., 29, 2:120-121. 
Maria Studnicka

\section{BADANIA NAD ZAWARTOŚCIA RTECIW MIEŚNIACH RYB POCHODZACCYCH Z NIEKTÓRYCH NATURALNYCH ZBIORNIKÓW WODNYCH POLSKI}

Streszczenie

Poziom rtẹci całkowitej oznaczano w mięśniach 582 ryb należących do 16 gatunków.

Badano ryby $z$ wód nieskażonych $-z$ gómego biegu trzech dopływów Wisły: Skawy, Dłubni, Sanu; z rzeki Tanwi oraz jezior łęczyńsko-włodawskich. W Wiśle, której wody sq zanieczyszczone sciekami przemysłowymi odławiano do badań ryby w czterech punktach: w okolicy Krakowa, Puław, Swiecia i Swibna.

Oznaczenia rtęci wykonano metoda spektrofotometrï atomowo-absorpcyjnej.

Stęienia rtęci całkowitej $w$ mięśniach ryb $z$ wód nieskażonych wahało się $w$ granicach $0,006-0,16 \mathrm{mg} / \mathrm{kg}$, a u $95 \%$ tych ryb wynosiło ponižej $0,1 \mathrm{mg} / \mathrm{kg}$.

Wszystkie badane ryby $z$ Wisły, niezależnie od miejsca odłowu, zawierały w tkance mięśniowej znacznie wyższe stężenia rtẹc (sięgające do $1,58 \mathrm{mg} / \mathrm{kg}$ ) aniżeli ryby odłowione w wodach nieskazonych. Stopień skazenia ryb z Wisły związkami rtęci jest znaczny, zwłaszcza ryb drapieżnych. U ryb roślinożemych oraz odżywiających się drobną fauna denną poziom rtęciw mięśniach nie przekraczał wartości $0,5 \mathrm{mg} / \mathrm{kg}$ (z wyjątkiem okolic Krakowa). Dane te sugerują, że istnieje prosta zależność stopnia gromadzenia rtęci od długości łańcucha pokannowego.

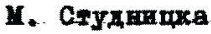

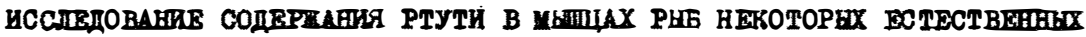 PEЗЕРВУАРОВ ПОЛЬШய}

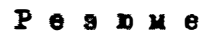

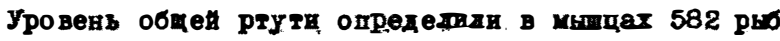
16 впдов. Иссдедовал

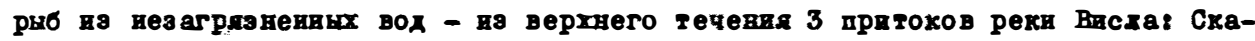

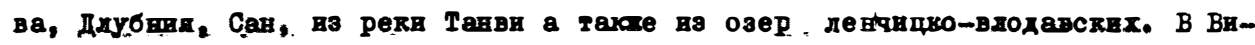

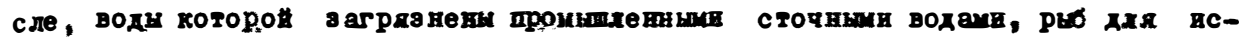

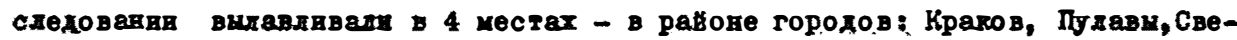

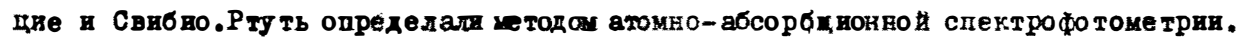

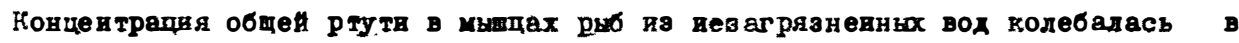

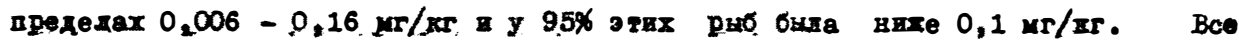

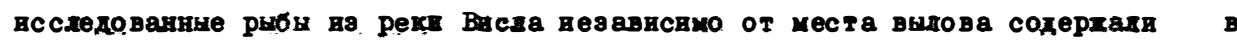

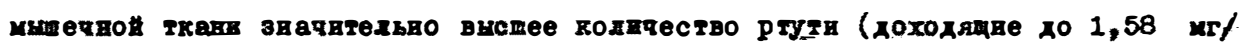

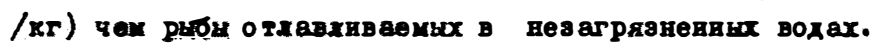




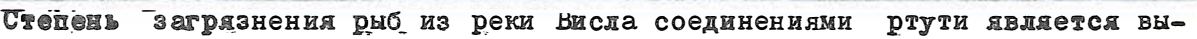

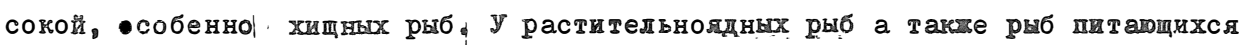

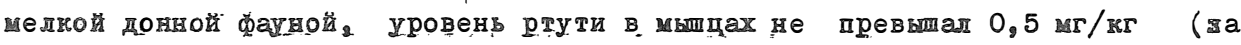
चсключениея окрестностей Кракова),Әти данные дают основаяие предполагать, что судестеет шрямая зависимость величнны накопления ртути от длшны пиMево留 цещи.

Ilepezon: dr Józer Domagala

Received: 6 VI 1980

Address:

Doc. dr hab. Maria Studnicka

Institute of Inland Fisheries

Laboratory of Ich thyobiology

Zabieniec k. Warszawy

05-500 Piaseczno

Polska (Poland) 